\title{
LOCAL TAXES AND CHARGES IN LOCAL BUDGETS' INCOME GENERATION
}

\author{
Halyna Rossikhina', Yuliia Svitlychna ${ }^{2}$, Oksana Brusakova ${ }^{3}$
}

\begin{abstract}
The aim of the article is to determine the role of local taxes and charges in local budgets'income generation, as well as to conduct a comparative legal study of regulatory legal acts that determine the legal basis for local budgets' income generation by local taxes and charges. The subject of the study is local taxes and charges in local budgets' income generation. Methodology. The study is based on the dialectical method of scientific knowledge and corresponding general scientific methods, such as analysis, comparative, analogy, induction, and others. The results of the study revealed that to implement positive foreign experience in generating incomes of local budgets, a number of negative aspects should be restricted. Unfortunately, the ratio of subventions and subsidies in the incomes of local budgets of Ukraine demonstrate no positive trend. In Ukraine, local bodies have very little and weak powers even for the use of funds distributed via the budgetary system. Therefore, most of the funds transferred from the State Budget of Ukraine to local budgets, in reality, are only their imaginary income. Practical implications. Local taxes and fees in the context of their participation in local budgets' income generation are under the study. Negative tendencies of a significant proportion of inter-budgetary transfers in the financial provision of regions and territorial communities are identified. The author argues that the increase in revenues from local taxes and charges, accretion of local bodies' tax powers is aimed at ensuring the independence of local budgets, reducing the burden on the State Budget of Ukraine. Relevance/originality. A legal analysis of local taxes and charges in local budgets' income generation and definition of problems in the budgetary sphere are the foundation for the development of the most promising spheres for domestic legislation improvement in respect of the aspect.
\end{abstract}

Key words: taxes and charges, local taxes and charges, budget, local budget, local budget incomes, inter-budget transfers.

JEL Classification: $\mathrm{H} 21, \mathrm{H} 24, \mathrm{H} 72$

\section{The relevance of the topic}

Nowadays, the globalization of society contributes to the positive cross-cultural interaction, strengthening of the country's potential through the accession to the best world intellectual achievements and study of historical experience in solving socially important issues (Sevruk, Pavlenko, 2015). Therefore, over the past decade, the radical socio-economic transformations have resulted in both positive and negative changes in contemporary Ukrainian society (Pavlenko, Sevruk, Kobko, 2017).

To a certain extent, it is expected that due to fixing at the local level important for the society functions, such as health care, education, social security, etc., the income generation of local budgets is ensured mostly by legislative consolidation and establishment of deductions from state tax payments. Nationally important, both in the context of taxation objects and in terms of their fiscal capacity, the latter can provide with a stable financial support for local infrastructure,

Corresponding author:

${ }^{1}$ V.N. Karazin Kharkiv National University, Ukraine.

${ }^{2}$ Kharkiv National University of Internal Affairs, Ukraine.

${ }^{3}$ Kharkiv National University of Internal Affairs, Ukraine. ensuring a state-guaranteed level of social security of the population, the performance of other local functions and tasks without any complicated reform of the fiscal system.

However, it should be considered that total tax revenues to the local budgets from national taxes and charges push back to the second plan incomes from tax payments. Objectively this poses serious threats of both the reduction of the importance of local taxes and charges in the financial security and economic development of the regions and the loss of interest of local representative bodies in their regulation and implementation within the limits of the granted powers.

\section{Literature review}

A significant contribution to the study of this problem was made by foreign and domestic scientists, such as P. M. Borovyk, V. V. Zubenko, M. P. Kucheriavenko, T. B. Lishchyna, O. Marchuk, O. A. Musyka, 
O. O. Nepochatenko, V. A. Nikolaev, S. O. Pavlenko, L. V. Pavlyichuk, V. Pysmennyi, V. V. Rudenko, A. Yu. Rudyk, I. V. Samchynska, V. G. Sevruk, A. Slobozhan, and others. The aim of the article is to define the role of local taxes and charges in local budgets' income generation, as well as to conduct a comparative legal study of regulatory legal acts that determine the legal basis for local budgets' income generation by local taxes and charges.

\section{The main material}

Russian scientist V. Nikolaev argues that under these conditions, the interest of local bodies in an active economic policy, aimed at stimulating business activity, developing competition, and supporting local private entrepreneurship, is excluded (Nikolaev, 2013). Furthermore, objectively the tendency to minimize the scope of tax powers of local bodies leads to shifting responsibility for the economic development of state territorial units to the central government. Thus, the preconditions for destabilization are rooted not only in the economic development of the state and its territories but also in the interests of all state administration.

Moreover, the shortcomings of excessive centralization of tax powers and insufficient consideration of economic interests of the regions may be less noticeable in short terms, under the veil of supposedly stable financial receipts from the centre, but amplified especially in the medium and long terms when macroeconomic indicators of the entire state are much weaker than in many developed countries of the world. These threats become even more urgent for our state under consideration of the formality of the majority of the tax powers of local self-government bodies in Ukraine, as discussed above.

In addition, according to the requirements of the provisions of Articles 69 and 71 of the Budget Code of Ukraine (Biudzhetnyi kodeks Ukrainy), both local taxes of the domestic tax system (unified tax and tax on immovable property other than the land plot) are assigned imperatively to a special fund of local budgets. Moreover, a narrow target area of such fund expenditures leads to a limitation in the ability of local bodies to operate freely with local finances, determine independently their uses, and rely on local tax revenues in local issues.

Moreover, it is generally accepted that, in comparison with tax collections, more than two-thirds of incomes to the revenue side of the budget are provided by taxes (Kucheriavenko, 2012). Therefore, since domestic legislation provides for that the general revenue fund of local budgets comprises only the charge for certain types of entrepreneurial activity, the tax for vehicle parking places and tourist tax, even more prerequisites for minimizing the importance of tax payments in local finances and the formation of public monetary funds occur.
In addition, the widespread use of inter-budgetary transfers (funds transferred free of charge and irrevocably from one budget to another) diminishes significantly the role of revenues from tax payments (Kucheriavenko, 2012). The main types of inter-budgetary transfers in Ukraine are the subsidy of equalization and subvention (Muzyka, 2004), which by their legal nature organize a downward flow of secondary revenues of the state budget system filling the system of local budgets with the revenues of the state budget.

In the mechanism of various incomes, inter-budgetary transfers become a powerful means of achieving the necessary level of financial security for regions and territorial communities. Article 97 of the Budget Code of Ukraine (Biudzhetnyi kodeks Ukrainy) details such inter-budgetary transfers additionally. According to its content, the state budget of Ukraine can provide such transfers to local budgets: 1) equalization subsidy for the budget of the Autonomous Republic of Crimea, regional budgets, district budgets, and budgets of the cities of the Republic of the Autonomous Republic of Crimea and regional significance, budgets of cities of Kyiv and Sevastopol, other budgets of local selfgovernment for which governmental inter-budgetary transfers are defined in the state budget; 2) additional equalization subsidy for the financial security of local budgets; 3) subventions for the implementation of state social protection programs; 4) additional subsidy for compensation of losses of local budget incomes due to the provision of benefits established by the state; 5) subvention for the construction, reconstruction, repair, and maintenance of streets and communal property roads in locality; 6) subvention for the implementation of investment programs; 7) other additional grants and other subventions.

Total subsidies and subventions are approved in the Law on the State Budget of Ukraine for the corresponding year separately for each of the local budgets. Thus, the legal regulation of inter-budgetary transfers is attributed to the powers of the highest state authorities. Such centralization causes the loss of interest of local bodies in strengthening local finance by increasing primary incomes of local budgets. Thus, the tax policy of local representative bodies is reduced to the unenterprising expectation of subsidies and subventions from the state budget. In these conditions, the independence of local budgets is significantly weakened, the burden on the state budget of the country is increasing, and the deficit of the latter is growing.

This problem is rooted in at least the first half of the last century and the times of the collapse of the Russian Empire and creation of the former USSR. For example, in May 1918, V.I. Lenin proclaimed theories of the uselessness of local self-government, need of the rigid centralization of financial management in general and taxation in particular, and abandonment of independent local budgets (Pysmennyi, 2010). Despite the intensive 
development of the institute of local finance over NEP years, since 1929, the local budgets of the USSR were completely dependent on the state budget (Pysmennyi, 2010); their management was generally controlled by the central authorities almost until the last years of the USSR. Nevertheless, even after the collapse of the latter, with the beginning of Ukraine's independence, the issue of the independence of local finances was not solved finally.

Another factor is that incomes from local taxes and charges are obviously insufficient. The following statistical data are the evidence (Zubenko, Samchynska, Rudyk et al., 2013). Thus, during 1998-2008, the share of local taxes among local budget incomes decreased from barely noticeable 2.6 percent in 1998 to miserable 0.6 percent in 2008. In the structure of all tax incomes of local budgets, including incomes from fixed and regulating nationwide tax payments, the outcome of local taxes and charges in this period ranged from 1.1 to 3.4 percent. Even the adoption of the Tax Code of Ukraine did not change significantly the suppressed position of local finances: according to available data (Cabinet of Ministers of Ukraine), the participation of local taxes and charges in financing local government expenditures from a catastrophic 0.5 percent in 2010 changed only to 2.5 percent in 2012 .

Undoubtedly, this situation requires changes. According to O.A. Musyka (Muzyka, 2004), the independence of budgets is possible only in the presence of own sources of revenue. This is evidenced by the experience of many economically developed countries, where own income are about half (from 40-60 percent) of local budgets' income. Above all, these revenues should be incomes from local taxes and charges.

At the same time, an increase in the financial potential of tax payments would be an important step to overcome the high subsidy percentage of local budgets. The latter, according to the Concept of Reforming Local Budgets, approved by the Decree of the Cabinet of Ministers of Ukraine No. 308-r of May 23, 2007 (Nepochatenko, Borovyk, Pavliychuk, 2012), is determined as one of the main problems that make it necessitate the reform of local budgets. Nevertheless, the concept has not solved this problem, but on the contrary, it becomes even more acute.

According to statistics (Slobozhan, November 22, 2013), since 2007, the share of inter-budgetary transfers in the total incomes of local budgets has been growing constantly in Ukraine. For example, in 2007, interbudgetary transfers of all kinds were up to 43.3 percent of incomes of local budgets, in 2008, up to 44.5 percent, in 2009, up to 46.7 percent, in 2010, up to 49.1 percent. The entry into force of the new Budget Code of Ukraine and the Tax Code of Ukraine did not change this trend. Moreover, in 2011, more than half of local budget revenues (up to 52.3 percent) was received out of inter-budgetary transfers, in 2012 , up to 53.6 percent).
According to the results of 2013 and current estimates, in Ukraine, a nation-wide share of inter-budgetary transfers is expected up to 55-56 percent of local budgets' incomes.

In fact, by the level of transfers from the state budget to local budgets' incomes, Ukraine has almost caught up with the Russian Federation. For the same indicator, the latter is at 61.8 percent in 2012 (Rudenko, Lishchyna). While developed European states are half that level of subsidy of local budgets (Rudenko, Lishchyna). For example, local budgets of the Kingdom of Sweden receive only 34 percent of revenues from the central budget of the state. The Federal Republic of Germany has achieved such a level of independence of local budgets that only 22 percent of their total incomes come from the state budget.

This situation on the accumulation of funds in the local budgets of Ukraine becomes very threatening for the entire public financial system of the state. In other words, in these circumstances, not only financial selfsufficiency and independence of local self-government decrease but also the situation with compiling and implementing the state budget of the country become more complicated. Frequently, warnings (Marchuk) are increased in connection of negative consequences of such a situation, since a significant part of state budget revenues is directed to the implementation of the budgetary regulation.

Therefore, in the context of the functional classification of expenditures and extending credit of the State Budget of Ukraine, the annual increase in the share of inter-budgetary transfers becomes clear (Cabinet of Ministers of Ukraine). For example, while in 2010, state budget expenditures in the form of downward inter-budgetary transfers to local budgets were up to 25.6 percent or 77766.2 million UAH and in 2011, up to 28.4 percent or 94875.0 million UAH, in 2012 , these indicators amounted up to 31.5 percent or 124459.6 million UAH, respectively.

Moreover, the evaluation of total subventions, that is, targeted inter-budgetary transfers to local budgets, which local authorities can direct only to a definite target, is no less important. According to domestic legislation [13], this target is determined by the body that has made the decision on subvention, i.e. central government bodies. Therefore, the greater the proportion of subventions in the funds coming from the state budget, the more formal the nature of fiscal powers of local bodies. Thus, the use of subvention proceeds becomes the most centralized form of various incomes. In fact, the next step of centralization can be only the liquidation of local finance and local selfgovernment as it has been done for most of the period of the former USSR.

Unfortunately, the ratio of subventions and subsidies in the incomes of local budgets of Ukraine demonstrate no positive trend. For example, while in 2005, 
this indicator was as low as the value of subventions from the state budget (42.3 percent) (Marchuk), in 2012, already up to 51.3 percent. Moreover, over 2005-2012, in Ukraine, on average, only 46 percent of inter-budgetary transfers to local budgets were equalization subsidies, which local governments can distribute and spend at own discretion. In most of the European countries, this proportion is much higher (Rudenko, Lishchyna): 62 percent in the Republic of Poland, 64 percent in the United Kingdom of Great Britain and Northern Ireland, 75 percent in the Kingdom of Sweden, and 95 percent in the Federal Republic of Germany. Only in the Russian Federation, indicators are almost the same as current ones in Ukraine, only 47 percent of subsidies among inter-budgetary transfers.

\section{Conclusions}

Such data mean that most of the funds transferred from the State Budget of Ukraine to local budgets, actually, are only their imaginary income. Local bodies list only technically most of the secondary revenues of local budgets to final recipients not being able to distribute them at own discretion. Moreover, considering the above circumstances for the barely perceptible share of local taxes and charges, most of which should be credited to a special fund of local budgets, it should be concluded that in Ukraine the mechanism of various incomes functions in one of the most unfavourable for local bodies regime. Local bodies in Ukraine have very small and weak powers, even using funds distributed via the budget system.

\section{References:}

Sevruk, V. H., Pavlenko, S. O. (2015). Zakhody protydii transnatsionalnomu narkobiznesu, shcho vchyniaietsia predstavnykamy okremykh etnichnykh hrup [Measures to counter transnational drug trafficking committed by representatives of certain ethnic groups]. Yurydychnyi chasopys Natsionalnoi akademii vnutrishnikh sprav, 2, $193-205$. (in Ukrainian)

Pavlenko, S., Sevruk, V., Kobko, Ye. (2017). Training police officers in the conditions of reforming the system of education of the ministry of internal affairs of Ukraine in accordance with European standards. Science and Education, 6, 142-150.

Nikolaev, V. A. (2013). Teoriia i praktika raspredeleniia nalogovykh polnomochiy v Rossii [Theory and practice of distribution of tax powers in Russia] (Monography). Moscow: Logos, 172 p. (in Russian)

Biudzhetnyi kodeks Ukrainy (no. 2456-VI of July 8, 2010). Vidomosti Verkhovnoi Rady Ukrainy, 50, 1778, Art. 572. (in Ukrainian)

Kucheriavenko, M. P. (2012). Podatkove pravo Ukrainy: Pidruchnyk [Tax Law of Ukraine: A teaching manual]. Kh.: Pravo, 528 p. (in Ukrainian)

Muzyka, O. A. (2004). Dokhody mistsevykh biudzhetiv za ukrainskym zakonodavstvom [Incomes of local budgets in Ukrainian legislation] (Monography). K.: Atika, 344 p. (in Ukrainian)

Pysmennyi, V. (2010). Podatkovyi aspekt zmitsnennia vlasnoi dokhidnoi bazy mistsevykh biudzhetiv Ukrainy [Tax aspect of strengthening own revenues base of local budgets of Ukraine]. Visnyk TNEU [Bulletin of TNEU], 2, 61-70. (in Ukrainian)

Zubenko, V. V., Samchynska, I. V., Rudyk, A. Yu. et al. (2013). Biudzhetnyi monitorynh: Analiz vykonannia biudzhetu za 2012 rik. K.: IBSED, 52 p. (in Ukrainian)

Cabinet of Ministers of Ukraine. (May 23, 2007). Pro skhvalennia Kontseptsii reformuvannia mistsevykh biudzhetiv [On approval of the Concept of reforming local budgets] (Order no.308-r). Ofitsiynyi visnyk Ukrainy, 38, 12. (in Ukrainian)

Nepochatenko, O. O., Borovyk, P. M., Pavliychuk, L. V. (2012). Mizhbiudzhetni transferty yak instrument vyrivniuvannia dokhodnoi spromozhnosti mistsevykh biudzhetiv [Inter-budgetary transfers as a tool for equalization of local budget revenues]. Stalyi rozvytok ekonomiky, 3, 287-290. (in Ukrainian)

Slobozhan, A. (November 22, 2013). Mestnoe samoupravlenie i evroperspektivy [Local self-government and Euro perspectives]. Zerkalo nedely. Ukrayna, 43. (in Russian)

Rudenko, V. V., Lishchyna, T. V. Otsinka efektyvnosti transfertnoi polityky derzhavy [Evaluation of the effectiveness of the state transfer policy]. Retrieved from: www.rusnauka.com (in Ukrainian)

Marchuk, O. Napriamy vdoskonalennia systemy mizhbiudzhetnykh vidnosyn v Ukraini [Directions of improvement of the system of inter-budgetary fiscal relations in Ukraine]. Retrieved from http://naub.oa.edu.ua (in Ukrainian) 